\title{
MANAJEMEN PESERTA DIDIK PADA TAMAN PENDIDIKAN ANAK USIA DINI DO'A IBU
}

\author{
Besse Marjani Alwi \\ Jurusan Pendidikan Islam Anak Usia Dini \\ Fakultas Tarbiyah dan Keguruan, UIN Alauddin Makassar \\ E-mail: marjanialwi@gmail.com \\ Suci Ramadani \\ Jurusan Pendidikan Islam Anak Usia Dini \\ Fakultas Tarbiyah dan Keguruan, UIN Alauddin Makassar \\ E-mail: sucirmdni99@gmail.com \\ Suhanir \\ Jurusan Pendidikan Islam Anak Usia Dini \\ Fakultas Tarbiyah dan Keguruan, UIN Alauddin Makassar \\ E-mail: suhaniranhi@gmail.com \\ Zulaika safira \\ Jurusan Pendidikan Islam Anak Usia Dini \\ Fakultas Tarbiyah dan Keguruan, UIN Alauddin Makassar \\ E-mail: ika11jan97@gmail.com \\ Tendri Herma \\ Jurusan Pendidikan Islam Anak Usia Dini \\ Fakultas Tarbiyah dan Keguruan, UIN Alauddin Makassar \\ E-mail: hermaabdullah15@gmail.com
}

\begin{abstract}
Abstrak
Penelitian ini bertujuan untuk mengetahui gambaran penerapan manajemen peserta didik di Taman Pendidikan Anak Usia Dini (PAUD) Do'a Ibu Jl. Tamalate 1 Kampus UNM IV Tidung Makassar. Jenis penelitian yang dilakukan adalah penelitian deskriptif kualitatif dengan mengambil salah satu guru di Taman Pendidkan anak usia dini Anak Usia Dini (PAUD) Do'a Ibu sebagai objek penelitian. Teknik pengumpulan data dilakukan dengan menggunakan wawancara terstruktur. Hasil penelitian menunjukkan bahwa Taman Pendidikan Anak Usia Dini (PAUD) Do'a Ibu telah memenuhi standar dalam manajemen peserta didik yaitu: a) Perencanaan peserta didik dilakukan dengan mempertimbangkan jumlah peserta didik serta rasio perbandingan antara guru dan anak. b) Kehadiran dan ketidakhadiran peserta didik dicatat kedalam buku absensi. c) Pencatatan dan pelaporan peserta didik dilaksanakan dalam bentuk buku induk anak serta buku alumni. d) Pembinaan peserta didik dilakukan melalui beberapa layanan yakni layanan bimbingan dan konseling serta layanan kesehatan. e) Evaluasi peserta didik dilakukan melalui beberapa cara yakni observasi, wawancara, dan portofolio. f) Kelulusan dan alumni peserta didik dibuktikan dengan pemberian ijazah. g) Mutasi peserta didik ditandai dengan pemberian surat pindah.
\end{abstract}


Kata Kunci: Manajemen, Pendidikan Anak Usia Dini, Peserta Didik

\begin{abstract}
This study aims to describe the management implementation of students in the Early Childhood Education (PAUD) Mother's Prayer Jl. Tamalate 1 UNM IV Campus, Tidung Makassar. This type of research is a qualitative descriptive study by taking one of the teachers at the Center for Early Childhood Prayer for Motherhood as the object of research. Data collection techniques are carried out using structured interviews. The results of the study show that the Early Childhood Education (PAUD) Park meets the standards in student management, namely: a) Student planning is done by considering the number of students and the ratio of the ratio between teacher and child. b) Attendance and absence of students is recorded in the attendance book. c) Recording and reporting of students is carried out in the form of master books and children's alumni books. d) Fostering students is carried out through several services, namely guidance and counseling services and health services. e) Student evaluation is carried out in several ways, namely observation, interviews, and portfolios. f) Graduation and student alumni are proven by giving a diploma. g) Mutation of students is marked by giving a transfer letter.
\end{abstract}

Keywords: Management, Early Childhood Education, Students

\title{
PENDAHULUAN
}

Pendidikan Nasional merupakan upaya mewujudkan amanat dalam Undang-Undang Dasar 1945 yakni mencerdaskan kehidupan bangsa. Pendidikan diharapkan dapat membantu manusia yang berkualitas yang memiliki kemampuan untuk menguasai, memanfaatkan dan mengembangkan ilmu pengetahuan dan teknologi guna mendukung pelaksanaan Pembangunan Nasional. Oleh karena itu, peningkatan kualitas pendidikan mutlak dilakukan terlebih lagi dalam rangka menghadapi era globalisasi seperti sekarang ini (Hesti Dwi Saptiningtyas, 2008).

PAUD merupakan pendidikan yang sangat mendasar dan strategis dalam pembangunan sumber daya manusia. Sesuai pasal 28 Undang-Undang Tahun 2003 tentang Sistem Pendidikan Nasional, PAUD telah ditempatkan sejajar dengan pendidikan lainnya. Hal ini menunjukkan bahwa secara yuridis formal, PAUD merupakan bagian yang tak terpisahkan dari keseluruhan Sistem Pendidikan Nasional. Walaupun pendidikan prasekolah bukan merupakan kewajiban dan prasyarat untuk memasuki sekolah dasar. (Rahman, 2002 dalam Hesti Dwi Saptiningtyas, 2008).

Dengan diberlakukannya UU No. 20 Tahun 2003 maka Sistem Pendidikan di Indonesia terdiri dari pendidikan anak usia dini, pendidikan dasar, pendidikan menengah, dan pendidikan tinggi, yang keseluruhannya merupakan kesatuan yang sistematik. PAUD diselenggarakan sebelum jenjang pendidikan dasar. PAUD dapat diselenggarakan melalui jalur formal, non formal, dan/ atau informal. PAUD pada jalur pendidikan formal berbentuk Taman kanak-kanak (TK), Raudhatul atfhal (RA), 
atau bentuk lain yang sederajat. PAUD pada jalur pendidikan nonformal berbentuk kelompok bermain (KB), Taman penitipan anak (TPA), atau bentuk lain yang sederajat. PAUD pada jalur pendidikan informal berbentuk pendidikan keluarga atau pendidikan yang diselenggarakan oleh lingkungan.

Manajemen menurut Etimologi berasal dari bahasa Inggris "management" yang dikembangkan dari kata "to manage", yang artinya mengatur atau mengelola. Kata "manage" ini sendiri berasal dari Italia "manegglo" yang diadopsi dari bahasa latin "managlare", yang berasal dari kata "manus" yang artinya tangan (Tim Dosen Administrasi Pendidikan UPI, 2011). Kamus Besar Bahasa Indonesia kata "Managemen" mempunyai pengertian sebagai penggunaan sumber daya secara efektif untuk mencapai sasaran (Yuku, 2013).

Dalam UU sistem pendidikan nasional tahun 2003 bahwa peserta didik adalah anggota masyarakat yang berusaha mengembangkan potensi diri melalui proses pembelajaran yang tersedia pada jalur, jenjang, dan jenis pendidikan tertentu. Abu Ahmadi berpendapat bahwa peserta didik adalah sosok manusia sebagai individu atau pribadi (manusia seutuhnya). Individu diartikan “orang yang tidak tergantung dari orang lain, dalam arti benar-benar seorang pribadi yang menentukan diri sendiri dan tidak dipaksa dari luar, mempunyai sifat-sifat dan keinginan sendiri" (Tim Dosen Administrasi UPI, 2009).

Manajemen peserta didik merupakan upaya untuk memberikan layanan sebaik mungkin kepada peserta didik sejak proses penerimaan sampai saat peserta didik meningggalkan lembaga pendidikan karena sudah lulus/tamat mengikuti pendidikan pada lembaga pendidikan tersebut (Tim Dosen Adpen UPI, 2011).

Manajemen peserta didik bertujuan untuk mengatur kegiatan-kegiatan peserta didik agar menunjang proses pembelajaran di PAUD sehingga proses pembelajaran berjalan lancar, tertib, teratur dan dapat memberikan kontribusi bagi pencapaian tujuan pembelajaran dan tujuan PAUD ecara efektif dan efesien. Manajemen peserta didik juga bertujuan untuk menciptakan kondisi lingkungan sekolah yang baik. Secara khusus, manajemen peserta didik bertujuan: (1) meningkatkan pengetahuan, keterampilan, dan psikomotorik peserta didik. (2) Menyalurkan dan mengembangkan kemampuan umum (kecerdasan), bakat, dan minat peserta didik. (3) Menyalurkan aspirasi, harapan, dan memenuhi kebutuhan peserta didik. (4) Peserta didik mencapai kebahagiaan dan kesejahteraan hidup yang lebih lanjut dapat belajar dengan baik dan mencapai cita-cita mereka (Badrudin, 2014).

Fungsi manajemen peserta didik secara umum adalah sebagai wahana bagi peserta didik untuk mengembangkan diri seoptimal mungkin, baik yang berkenaan dengan dimensi-dimensi individu, sosial, aspirasi, kebutuhanya, dan dimensi potensi peserta didik lainnya. Fungsi manajemen peserta didik secara khusus, yaitu: (1) Fungsi berkenaan dengan pengembangan individualitas peserta didik, ialah agar mereka dapat mengembangkan potensi-potensi individualitasnya tanpa banyak terhambat. (2) Fungsi yang berkenaan dengan pengembangan fungsi sosial peserta 
didik ialah agar peserta didik dapat mengadakan sosialisasi dengan sebayanya, dengan orang tua dan keluarganya, dengan lingkungan sosialnya, dan lingkungan social masyarakatnya. (3) Fungsi yang berkenaan dengan penyaluran aspirasi dan harapan peserta didik, ialah agar peserta didik dapat menyalurkan hobbi, kesenangan, dan minat. (4) Fungsi yang berkenaaan dengan pemenuhan kebutuhan dan kesejahteraan peserta didik ialah agar peserta didik sejahtera dalam hidupnya (Badrudin, 2014).

Ada 2 pendekatan yang digunakan manajemen peserta didik. Pertama, pendekatan kuantitatif (the quantitative approach). Pendekatan ini lebih menitik beratkan pada segi-segi administratif dan birokratik lembaga pendidikan. Dalam pendekatan demikian, peserta didik diharapkan banyak memenuhi tuntutantuntutan dan harapan-harapan lembaga pendidikan ditempat peserta didik tersebut berada. Kedua, pendekatan kualitatif (the qualitative approach). Pendekatan ini lebih memberikan perhatian pada kesejahteraan peserta didik. Jika pendekatan kuantitatif diatas diarahkan agar peserta didik mampu, maka pendekatan kualitatif ini lebih diarahkan pada peserta didik senang.

Prinsip dasar manajemen peserta didik, yaitu: (a) siswa harus diperlakukan sebagai subjek bukan objek, (2) keadaan dan kondisi siswa sangat beragam, ditinjau dari kondisi fisik, kemampuan intelektual, sosial ekonomi, minat dan sebagainya, (c) pada dasarnya siswa hanya akan termotivasi belajar jika mereka menyenangi apa yang diajarkan, (d) mengembangan potensi siswa tidak hanya menyangkut rana kognitif, tetapi juga afektif dan psikomotorik (A Ghoni, 2016).

\section{METODE PENELITIAN}

Jenis penelitian ini merupakan jenis penelitian Deskriptif Kualitatif. Sumber data dalam penelitian ini yang sekaligus menjadi informan yaitu salah satu guru di Taman PAUD Do'a Ibu yang beralamat di BTN Patri Abdullah, Kelurahan Samata, Kecamatan Somba Opu, Kabupaten Gowa, Sulawesi selatan. Adapun pemilihan sekolah berdasarkan kriteria: (1) Minimal telah menamatkan anak didik selama 3 tahun; (2) Dapat izin operasional darl Dinas pendidikan; (3) Mudah diakses oleh peneliti. Teknik pengumpulan data dilakukan menggunakan wawancara terstruktur, peneliti membuat daftar pertanyaan serta jawaban alternatif dari pertanyaan tersebut yang kemudian diajukan kepada responden.

\section{HASIL DAN PEMBAHASAN}

Adapun visi Taman PAUD Do'a Ibu yaitu Membentuk generasi anak didik yang sehat dan berkarakter. Misi Taman PAUD Doa Ibu yakni: 1) Menyelenggarakan layanan pengembangan pembelajaran yangberkarakter, 2) Memfasilitasi PAIKEM BROT (Pembelajaran Aktif, Inovatif, Kreatif, Efektif, Menyenangkan, dan Berbobot), 3) Membangun pembiasaan perilaku hidup sehat dan berkarakter, 4) Membangun kerjasama dengan orang tua, masyarakat, dan lingkup terkait dalam rangka 
pengelolaan PAUD yang professional dan berkarakter.

Tujuan dari Taman PAUD Do'a Ibu, yaitu: 1) Terwujudnya anak yang berkarakter religious, jujur, disiplin, kerja keras, kreatif, mandiri, rasa ingin tahu, menghargai prestasi, 2) Terwujudnya anak yang berkarakter toleransi, demokratis, bersahabat/komunikatif, cinta damai, peduli, 3) Terwujudnya anak yang berkarakter semangat kebangsaan dan cinta tanah air, 4) Terciptanya suasana yang kondusif dan menyenangkan bagi penyelenggara pendidikan, perawatan, pengasuhan, serta perlindungan anak.

Pada hasil penelitian ini, ruang lingkup dalam pembahasan manajemen peserta didik akan dijelaskan yaitu: a) Perencanaan peserta didik, b) Mengatur kehadiran dan ketidakhadiran peserta didik, c) Pencatatan dan pelaporan peserta didik, d) Pembinaan peserta didik, e) Evaluasi peserta didik, f) Kelulusan dan alumni, dan, g) Mutasi peserta didik. Hasil penelitian melalui observasi dan wawancara pada bulan Desember 2018 mengenai manajemen peserta didik di Taman PAUD Doa Ibu dapat dipaparkan sebagai berikut:

\section{Perencanaan peserta didik}

Hal pertama yang dilakukan dalam perencanaan peserta didik yaitu dengan menganalisis kebutuhan peserta didik melalui tahapan perencanaan jumlah peserta didik yang akan diterima dengan mempertimbangkan daya tampung dan jumlah kelas yang tersedia, serta mempertimbangkan rasio murid dan guru.

Jumlah peserta didik di Taman PAUD Doa Ibu berdasarkan wawancara dengan informan pertama selaku pendidik yaitu terdiri dari 14-15 anak untuk kelompok A dan 11 anak untuk kelompok B. Setiap kelompok di tempatkan satu kelas dengan masing-masing 1 guru sebagai guru kelas. Jika jumlah anak yang hadir lengkap atau jika suasana terlihat padat maka satu kelas didampingi oleh 1 guru kelas dan 1 guru pendamping. Jumlah pendidik di Taman PAUD Do'a Ibu terdiri dari 4 guru dan kepala sekolah.

Kedua yaitu rekrutmen peserta didik. Penerimaan peserta di Taman PAUD Do'a Ibu di buka setiap saat tetapi jika berdasarkan kalender pendidikan pendaftaran secara resmi di buka pada bulan Maret. Informasi pendaftaran biasanya disampaikan melalui sosial media, brosur, dari mulut ke mulut, serta dari alumnialumni PAUD tersebut. Di Taman PAUD Do'a Ibu tidak ada seleksi khusus yang dilakukan untuk masuk sekolah, hanya saja ada persyaratan khusus yang harus dipenuhi seperti usia minimal 2 tahun, mengisi formulir, serta melengkapi data-data.

Di Taman PAUD Do'a Ibu tidak dibentuk panitia penerimaan peserta didik secara khusus, tetapi hal itu dilakukan oleh masing-masing guru secara bergantian. Peserta didik yang telah melengkapi syarat-syarat pendaftaran, telah melakukan pengembalian formulir, dan melakukan pendaftaran ulang maka sudah tercatat sebagai peserta didik di PAUD tersebut dan terhitung mulai bulan Juli di setiap tahun berjalan. 
Ketiga, yaitu seleksi peserta didik. Di Taman PAUD Do'a Ibu tidak ada seleksi khusus yang dilakukan dalam hal penerimaan peserta didik hanya saja ada ketentuan yang berlaku di sekolah itu, diantaranya usia anak.

Keempat, yaitu orientasi peserta didik. Orientasi di Taman PAUD Do'a Ibu terdiri dari kegiatan pengenalan situasi dan kondisi TK, yaitu anak diperkenalkan dengan lingkungan sekolah, perkenalan dengan pendidik, serta sarana dan prasarananya, seperti alat permainan, ruang belajar, dan lainnya.

Kelima, yaitu penempatan peserta didik (pembagian kelas). Pembagian peserta didik di Taman PAUD Do'a Ibu dilakukan dengan sistem pengelompokan berdasarkan usia anak. Usia 2 tahun di tempatkan di TPA (Tempat penitipan anak). Usia 3-4 tahun di tempatkan di KB (Kelompok Bermain). Usia 4 - 5 tahun di tempatkan di kelompok A sedangkan usia 5 - 6tahun di tempatkan di kelompok B.

Pengelompokan peserta didik menurut William A Jagger dapat didasarkan atas: 1) Fungsi Integrasi, pengelompokan yang didasarkan kesamaan yang ada pada peserta didik (jenis kelamin, umur, dII). 2) Fungsi perbedaan, pengelompokkan berdasarkan perbedaan yang ada dalam individu peserta didik (minat, bakat, kemampuan, dII) (Aditya, Wahyu, dan Tukiran, 2017).

Keenam, yaitu pencatatan dan pelaporan peserta didik. Di TK Do'a Ibu pencatatan dan pelaporan peserta didik dimulai sejak nama anak mulai terdaftar di sekolah sampai anak tamat atau meninggalkan sekolah.

Rasio jumlah peserta didik di Taman PAUD Do'a Ibu sudah memenuhi syarat sesuai dengan yang tercantum dalam Peraturan menteri pendidikan dan kebudayaan. Permendikbud No. 137 tahun 2014 tentang standar pendidikan anak usia dini (PAUD) diatur sebagai berikut: (1) Lembaga PAUD anak usia dini berusia hingga 2 tahun yakni tempat penitipan anak (TPA), rasio guru dan anak harus dipenuhi adalah1:4 artinya 1 orang guru melayani maksimal 4 orang anak didik. (2) PAUD dengan anak didik usia 2-4 tahun maka rasio guru dan anak maksimal 1:8. (3) PAUD dengan anak didik berusia 4-6 tahun, yakni untuk jenjang kelompok bermain (KB) dan taman kanak-kanak (TK), rasio guru dan anak maksimal 1:15 dengan demikian dapat dipahami bahwa 1 orang guru KB ataupun TK sebaiknya tidak melayani lebih dari 15 orang anak didik.

\section{Mengatur kehadiran dan ketidakhadiran peserta didik}

Kehadiran peserta didik di sekolah adalah suatu kondisi yang memungkinkan terjadinya interaksi belajar mengajar. Peserta didik yang hadir lebih memungkinkan untuk terlibat aktif dalam interaksi tersebut, dan tidak demikian bagi peserta didik yang tidak hadir. Menurut Ali Imron ketidakhadiran siswa di sekolah dibagi menjadi tiga, yaitu: 1) Ketidakhadiran tanpa member ijin, 2) Ketidakhadiran beberapa jam pelajaran karena terlambat, 3) Ketidakhadiran dengan memberikan izin. Serta ada empat sumber penyebab ketidakhadiran siswa ke sekolah, yaitu: 1) Ketidakhadiran siswa yang bersumber dari keluarga, 2) Ketidakhadiran yang bersumber dari 
siswanya sendiri, 3) Ketidakhadiran yang bersumber dari lingkungan sekolah, 4) Ketidakhadiran yang bersumber dari lingkungan masyarakat (A Ghoni, 2016).

Di Taman PAUD Do'a Ibu kehadiran dan ketidakhadiran peserta didik dicatat di didalam Absen yang diisi dengan simbol-simbol ( $A=A l f a, ~ I=I z i n, ~ S=S a k i t)$ hal ini sesuai dengan ketentuan disekolah pada umunya.

\section{Pencatatan dan pelaporan peserta didik}

Pencatatan dan pelaporan peserta didik dimulai pada saat anak memasuki sekolah sampai anak tamat/lulus atau saat anak meninggalkan sekolah. Pencatatan peserta didik bertujuan agar lembaga dapat memberikan pelayanan yang optimal untuk peserta didik. Pelaporan bertujuan sebagai bentuk pertanggung jawaban lembaga kepada pihak-pihak yang dapat mengetahui perkembangan peserta didik, misalnya orangtua anak dan lain-lain.

Di Taman PAUD Do'a Ibu bentuk pencatatan dan pelaporan yang digunakan yaitu berupa buku induk siswa berisi catatan peserta didik yang masuk di sekolah. Buku alumni yang berisi catatan tentang anak yang selesai/tamat dan telah meninggalkan sekolah.

\section{Pembinaan Peserta Didik}

Menurut Tatang M. Amirin, dkk (2010:53-55) layanan peserta didik meliputi berbagai macam. Berikut ini bentuk layanan khusus yang digunakan sebagai penunjang manajemen peseta didik. (1) Layanan bimbingan dan Konseling, merupakan proses pemberian bantuan terhadap siswa agar perkembangannya optimal sehingga anak didik bisa mengarahkan dirinya dalam bertindak dan bersikap seusai dengan tuntutan dan situasi lingkungan sekolah, keluarga dan masyarakat. (2) Layanan perpustakaan, layanan ini ditujukan untuk menunjang proses pembelajaran di sekolah, melayani informasi yang dibutuhkan serta meberikan layanan irekreatif melalui koreksi bahan pustaka. (3) Layanan kantin, ditujukan agar guru dapat mengontrol dan berkonsultasi dengan pengelola kantin dalam menyediakan makanan yang sehat dan bernutrisi. (4) Layanan kesehatan, layanan kesehatan ini berbentuk UKS (Usaha Kesehatan Sekolah). Program UKS adalah mencapai lingkungan hidup yang sehat, pendidikan kesehatan, dan pemeliharaan kesehatan di sekolah. (5) Layanan transportasi, digunakan sebagai penunjang untuk kelancaran proses belajar mengajar, biasanya diperlukan bagi peserta didik tingkat Pra sekolah dan pendidikan dasar. (6) Layanan asrama, layanan asrama digunakan untuk mereka yang jauh dari keluarga, biasanya yang mengadakan layanan ini.

Pembinaan terhadap peserta didik di Taman PAUD Do'a Ibu meliputi beberapa layanan-layanan khusus yang menunjang manajemen peserta didik, yaitu: 1) Layanan bimbingan dan konseling, layanan BK pada Taman PAUD Doa Ibu yaitu dilakukan dengan cara guru berkomunikasi langsung dengan orang tua anak mengenai kondisi dan perkembangan anak dan kemudian diberikan saran ataupun solusi. 2) Layanan kesehatan, untuk layanan kesehatan di Taman PAUD Doa lbu yaitu 
disediakan UKS serta pihak sekolah bekerjasama dengan puskesmas untuk pemeriksaan kesehatan setiap 6 bulan sekali, misalnya pemberian vaksin dan sebagainya.

\section{Evaluasi Kegiatan Peserta Didik}

Istilah penilaian/evaluasi merupakan istilah yang sudah tidak asing lagi. Penilaian dalam konteks pembelajaran di pendidikan Anak Usia Dini (PAUD) adalah upaya mengumpulkan, menganalisis, dan menafsirkan berbagai informasi tentang kinerja dan kemajuan berbagai aspek perkembangan yang dapat dicapai oleh anak setelah mengikuti kegiatan pembiasaan dalam kurung waktu tertentu. Penilaian adalah proses pengumpulan dan pengolahan informasi untuk menentukan tingkat pencapaian perkembangan anak (Kemendiknas: 2010).

Menurut Mulyasa (2012:195), penilaian merupakan suatu proses pengumpulan, pelaporan, dan penggunaan informasi tentang hasil belajar anak dengan menerapkan prinsip-prinsip penilaian, pelaksanaan berkelanjutan, buktibukti autentik, akurat dan konsisten.

Di Taman PAUD Do'a Ibu evaluasi dilakukan setiap hari setelah proses pembelajaran berlangsung, untuk penilaian akhir dikumpulkan dari hasil penilaian yang dilakukan secara harian kemudian di Reckup. Tidak ada ujian akhir yang dilakukan pada Taman PAUD ini, yang dilakukan hanya pengayaan untuk anak-anak yang dinilai belum memenuhi semua indikator pencapaian perkembangan.

Ada beberapa teknik penilaian yang diterapkan di Taman PAUD Do'a Ibu yaitu: (1) Observasi, observasi merupakan teknik penilaian yang dilakukan dengan cara mengamati secara langsung perubahan atau perkembangan yang terjadi pada anak. Salah satu alat yang digunakan untuk perekaman hasil observasi yang digunakan di Taman PAUD Do'a Ibu yaitu melalui sistem checklist, dalam checklist tersebut memuat seluruh indikator pencapaian perkembangan setiap Kompetensi Dasar (KD). (2) Wawancara. Teknik penilaian ini biasanya dilakukan setiap kali anak selesai melakukan kegiatan. Pada umumnya anak diberikan beberapa pertanyaan singkat mengenai perasaannya setelah melakukan kegiatan tertentu, hal ini biasa digunakan untuk mengukur kemampuan kognitif serta perkembangan bahasa anak. (3) Portofolio, portofolio merupakan penilaian yang diperoleh dari kumpulan informasi perkembangan anak, baik berupa catatan anekdot, hasil karya, unjuk kerja, dan lain-lain.

Metode penilaian yang diterapkan di Taman PAUD Do'a Ibu sudah sesuai dengan standar metode penilaian pada umunya. Menurut Waseso (2005) terdapat beberapa metode penilaian PAUD, yaitu pertama, observasi atau pengamatan yang merupakan bagian kesatuan dari kegiatan pembelajaran dengan cara mengamati perilaku anak-anak. Kedua, wawancara yang berupa interaksi dialogis yang disesuaikan dengan tingkat perkembangan anak yang dilakukan sambil bermain. Ketiga, portofolio berupa penilaian yang mendasarkan pada kumpulan catatan dan 
hasil kerja anak. Kumpulan informasi ini dapat memberi gambaran pada nilai tentang sejauh mana perilaku dan keterampilan anak berkembang, catatan yang dilihat dapat berupa catatan-catatan anekdot, checklist, skala jenjang, serta formatformat lain yang menggambarkan perkembangan keterampilan atau perilaku anak (Ayriza, 4-8).

\section{Kelulusan dan alumni}

Proses kelulusan merupakan proses akhir dari manajemen peserta didik. Kelulusan merupakan pernyataan dari lembaga bahwa peserta didik telah menyelesaikan program pendidikan yang diikuti. Untuk Taman kanak-kanak yaitu telah menyelesaikan dua semester di kelompok A dan dua semester di kelompok B. Di Taman PAUD Do'a Ibu pernyataan kelulusan di tandai dengan pengeluaran ijazah yang dikeluarkan oleh Dinas pendidikan Kota Makassar serta namanya akan terdaftar di buku alumni pada sekolah tersebut.

\section{Mutasi Peserta Didik}

Di Taman PAUD Do'a Ibu anak yang ingin pindah diberikan tanda bukti berupa surat pindah oleh pihak sekolah. Anak yang ingin pindah ke Taman PAUD Do'a Ibu cukup mencantumkan surat pindah serta identitas yang kemudian diproses oleh pihak sekolah. Pengelompokan kelas bagi anak pindahan di tempatkan berdasarkan usianya.

\section{SIMPULAN}

Hasil penelitian di Taman PAUD Do'a Ibu menunjukan bahwa PAUD ini telah memenuhi beberapa ruang lingkup dalam manajemen peserta didik yaitu: a) Perencanaan peserta didik dilakukan dengan mempertimbangkan jumlah peserta didik serta rasio perbandingan antara guru dan anak. b) Kehadiran dan ketidakhadiran peserta didik dicatat kedalam buku absensi. c) Pencatatan dan pelaporan peserta didik dilaksanakan dalam bentuk buku induk anak serta buku alumni. d) Pembinaan peserta didik dilakukan melalui beberapa layanan yakni layanan bimbingan dan konseling serta layanan kesehatan. e) Evaluasi peserta didik dilakukan melalui beberapa carayakni observasi, wawancara, dan portopolio. f) Kelulusan dan alumni peserta didik dibuktikan dengan pemberian ijazah. g) Mutasi peserta didik ditandai dengan pemberian surat pindah.

\section{DAFTAR PUSTAKA}

Ayriza, Yulia. Metode Penilaian Perkembangan Anak Usia Dini http://staff.uny.ac.id/sites/default/files/pengabdian/dra-yulia-ayriza-msi-phd/g-metode-penilaian-perkembangan-bpkb.pdf

Badrudin. (2014). Manajemen Peserta Didik. Jakarta:PT Indeks 
Perdana, A, P., Nugroho, W, A., \& Tukiran (2016). Manajemen Peserta Didik. Ponorogo: Universitas Muhammadiyah Ponorogo. https://nuwamajournalist.files.wordpress.com/2018/01/makalahmanajemen-pesertadidik.pdf\&ved=2ahUKEwjm8c6VkcffAhWPiHAKHa8ND5AQFjAHegQIBxAB\&usg =AOvVaw2Mx8mC8j0UozICJp7lyfJ3

Saptaningtyas., H.D. (2008). Kajian Kesesuaian Antara Permintaan Dan PenyediaanLembaga Pendidikan Anak Usia Dini Jalur Non Formal Di Kecamatan Jebres Kota Surakarta. Tesis.https://core.ac.uk/download/pdf/11717325.pdf. Semarang: Universitas Diponegoro.

Syamsuddin. (2017). Penerapan Fungsi-Fungsi Manajemen Dalam Meningkatkan Mutu Pendidikan. Jurnal Idaarah(Online), Vol I No.1 Tahun 2017 http://journal.uinalauddin.ac.id/index.php/idaarah/article/download/4084/3773

Zahro, F, I. (2016). Penilaian Dalam Pembelajaran Anak Usia Dini. Jurnal PG PAUD STKIP Siliwangi. Volume 1 Nomor 1, Oktober 2015: 92-111 www.google.com/search?safe=strict\&oq=aqs=mobile-gwslite.1.35i39l3...3\&q=manajemen+penilaian+paud+jurnal+pdf. 